\title{
REVIEW
}

\section{Seagrass nutrient content}

\author{
Carlos M. Duarte
}

Centro de Estudios Avanzados de Blanes, Camino de Santa Barbara s/n, E-17300 Blanes, Gerona, Spain

\begin{abstract}
Data on nutrient contents of 27 seagrass species at 30 locations were compiled from the literature. Mean ( \pm SE) concentrations of carbon, nitrogen and phosphorus in seagrass leaves were 33.6 $\pm 0.31,1.92 \pm 0.05$, and $0.23 \pm 0.011 \%$ dry wt, respectively. The median C:N:P ratio was $474: 24: 1$, which represents a C:P ratio more than 4 times, and a N:P ratio more than 1.5 times that of oceanic seston. These ratios are, however, less than those previously reported for marine macrophytes (550:30:1) by Atkinson \& Smith (1984). Nitrogen and phosphorus variability within species was large, but carbon contents exhibited little variability. Accordingly, carbon:nutrient ( $N$ and P) ratios were inversely related to changes in nutrient content, and the rate of change in $C: N$ and $C: P$ ratios with increasing nitrogen or phosphorus content in plant tissues should shift from high to small as nutrient supply meets the plant's demands. The median nitrogen and phosphorus contents reported here $(1.8 \%$ $\mathrm{N}$ and $0.20 \% \mathrm{P}$ as \% DW) correctly discriminated between seagrass stands that did or did not respond to nutrient enrichment, thus offering a useful reference for comparisons of seagrass nutrient contents.
\end{abstract}

\section{INTRODUCTION}

The importance of nutrient limitation as a constraint to seagrass growth is still subject of controversy (e.g. Patriquin 1972, Short 1987, Zimmerman et al. 1987) because few direct growth experiments are available. Attempts to infer nutrient limitation from nutrient concentrations in plant tissues (cf. Atkinson \& Smith 1984 , Short 1987) have also failed to yield conclusive generalities because (1) the data examined were few, and (2) the nutritional content of the plants must be compared against values indicative of nutrientbalanced growth, which are as yet unknown for seagrasses. Thus, Atkinson \& Smith (1984) observed N:P and C:P ratios in seagrass tissues well above the Redfield value for oceanic seston, but could not conclude whether this reflected intrinsic differences in the structure of seagrasses or widespread nutrient (phosphorus) limitation for the species examined. However, new data on seagrass nutrient contents have become available since a broad comparison was first attempted (Atkinson \& Smith 1984), so that a reassessment of seagrass nutrient contents may partially palliate the weaknesses of earlier efforts.
Here I compare the nutrient contents (and their ratios) in leaves of seagrass, representing a broad compilation (27 species collected from 30 locations) of available data in order to: (1) establish the ranges and variability of carbon, phosphorus, and nitrogen contents possible for seagrasses; (2) identify the extent of within-species and among-species variability in seagrass nutrient content; and (3) examine patterns in changes in nutrient content and nutrient ratios among seagrasses.

\section{METHODS}

Data on carbon, nitrogen, and phosphorus concentrations in leaves of seagrass communities distributed worldwide were collected from the available literature (Table 1). Nutrient concentrations were converted, when necessary, to nutrient weight as percent of leaf dry weight and nutrient ratios to atomic ratios, which are the units more commonly used in the literature. Most determinations of carbon concentrations of seagrass leaves were obtained by oxidation using $\mathrm{CHN}$ analyzers; determinations of nitrogen concentrations, by using the Kjeldahl technique or CHN analyzers; 
Table 1. Sources of data on seagrass nutrient contents. Asterisks indicate sources of data on seagrass responses to nutrient enrichments

\begin{tabular}{|c|c|c|}
\hline Species & Location & Sources \\
\hline Amphibolis antarctica & W Australia & Walker \& McComb (1988) \\
\hline Amphibolis griffithui & W Australia & Atkinson \& Smith (1984) \\
\hline \multirow[t]{5}{*}{ Cymodocea nodosa } & Corsica & Atkinson \& Smith (1984) \\
\hline & Italy & Pirc \& Wollenweber (1988) \\
\hline & NE Spain & Delgado (1986) \\
\hline & NE Spain & Perez (1989) \\
\hline & NE Spain & Perez et al. $(1990)^{\circ}$ \\
\hline \multirow[t]{3}{*}{ Cymodoceá serrulata } & N Queensland & Atkinson \& Smith (1984) \\
\hline & N Queensland & Birch (1975) \\
\hline & SE Queensland & Boon (1986) \\
\hline \multirow[t]{2}{*}{ Enhalus acoroides } & N Queensland, Palau & Atkinson \& Smith (1984) \\
\hline & N Queensland & Birch (1975) \\
\hline \multirow[t]{3}{*}{ Halodule uninervis } & N Queensland & Atkinson \& Smith (1984) \\
\hline & N Queensland & Birch (1975) \\
\hline & Red Sea & Wahbeh (1988) \\
\hline Halodule wrightii & Florida & Powell et al. $(1989)^{\circ}$ \\
\hline Halophila decipiens & N Queensland & Birch (1975) \\
\hline Halophila hawailana & Hawaii & Atkinson \& Smith (1984) \\
\hline \multirow[t]{2}{*}{ Halophila ovalis } & W Australia & Atkinson \& Smith (1984) \\
\hline & N Queensland & Birch (1975) \\
\hline \multirow[t]{2}{*}{ Halophila spinulosa } & N Queensland & Atkinson \& Smith (1984) \\
\hline & N Queensland & Birch (1975) \\
\hline Halophila stipulacea & Red Sea & Wahbeh (1988) \\
\hline Heterozostera tasmanica & Victoria & Bulthuis \& Woelkerling (1981) \\
\hline Phyllospadix scouleri & California & Atkinson \& Smith (1984) \\
\hline \multirow[t]{3}{*}{ Posidonia australis } & W Australia & Walker \& McComb (1988) \\
\hline & W Australia & Hocking et al. (1981) \\
\hline & S Australia & Augier et al. (1982) \\
\hline \multirow[t]{4}{*}{ Posidonia oceanica } & E France & Augier et al. (1982) \\
\hline & Italy & Pirc \& Wollenweber (1988) \\
\hline & NE Spain & Delgado $(1986)$ \\
\hline & Corsica & Atkinson \& Smith (1984) \\
\hline Posidonia ostenfeldia & W Australia & Atkinson \& Smith (1984) \\
\hline \multirow[t]{2}{*}{ Posidonia sinuosa } & W Australia & Hocking et al. (1981) \\
\hline & W Australia & Atkinson \& Smith (1984) \\
\hline \multirow[t]{3}{*}{ Ruppia maritima } & Virginia & Atkinson \& Smith (1984) \\
\hline & NE Spain & Perez (1989) \\
\hline & NE Spain & Delgado (1986) \\
\hline Syringodium filiforme & Bahamas & Short et al. (1985) \\
\hline Syringodium isoetifolium & N Queensland & Birch (1975) \\
\hline Thalassia hemprichii & N Queensland & Atkinson \& Smith (1984) \\
\hline \multirow[t]{7}{*}{ Thalassia testudinum } & Florida & Powell et al. (1989) \\
\hline & Florida & Kenworthy \& Thayer (1984) \\
\hline & Florida & Knauer \& Ayers (1977) \\
\hline & Florida & Rublee \& Roman (1982) \\
\hline & Virgin I. & Zieman et al. (1984) \\
\hline & Bimini & Capone et al. (1979) \\
\hline & Barbados & Patriquin (1972) \\
\hline Zoltera noltii & Italy & Pirc \& Wollenweber (1988) \\
\hline \multirow[t]{3}{*}{ Zostera capricornii } & SE Queensland & Boon $(1986)$ \\
\hline & N Queensland & Atkinson \& Smith (1984) \\
\hline & N Queensland & Birch (1975) \\
\hline \multirow[t]{10}{*}{ Zostera marina } & NE USA & Atkinson \& Smith (1984) \\
\hline & Rhode Island & Harlin \& Thorne-Miller $(1981)^{\circ}$ \\
\hline & Netherlands & Pellikaan $(1982)$ \\
\hline & Netherlands & Pellikaan \& Nienhuis (1988) \\
\hline & Japan & Umebayashi (1989) \\
\hline & Japan & Umebayashi \& Sasaki (1985) \\
\hline & Virginia & Kenworthy \& Thayer (1984) \\
\hline & Alaska & Short (1983) \\
\hline & New Hampshire & Short $(1987)^{\circ}$ \\
\hline & N Carolina & Thayer et al. (1977) \\
\hline
\end{tabular}


most determinations of phosphorus concentrations used a molybdate procedure following persulfate digestion.

\section{RESULTS AND DISCUSSION}

Average ( \pm SE) nutrient concentrations (as \% DW) were $33.6 \pm 0.31$ carbon, $1.92 \pm 0.05$ nitrogen, and $0.23 \pm 0.011$ phosphorus, with considerable variation around these average values (Fig. 1). The shape of the distribution of values of seagrass carbon contents was approximately normal (Fig. 1), whereas the distributions of nitrogen and phosphorus contentes were positively skewed (Fig. 1), indicating that nutrient contents were low in most stands examined, whereas a few stands had very high nutrient contents. The distributions of nitrogen and phosphorus contents suggested the existence of a lower limit to the nutrient content for seagrass survival, since values below $1.0 \% \mathrm{~N}$ and $0.1 \% \mathrm{P}$ of plant dry weight were rare (Fig. 1).
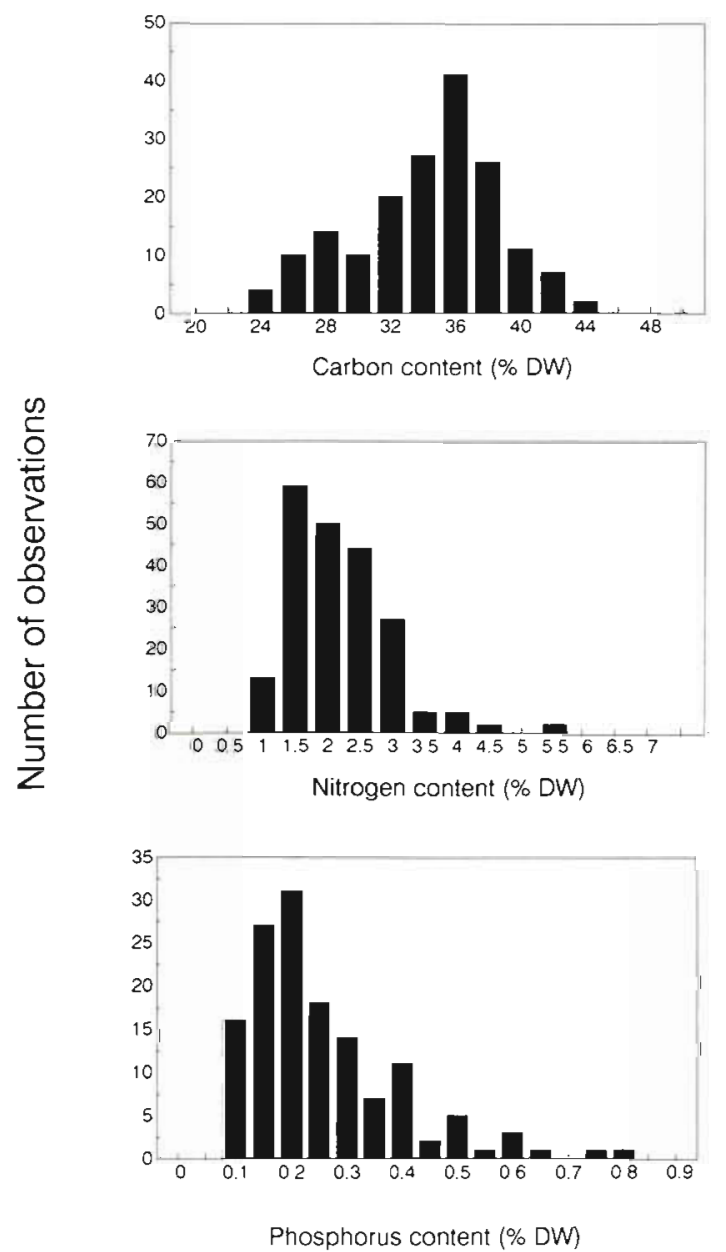

Fig.1. Frequency distribution of carbon, nitrogen, and phosphorus contents of seagrass leaves
Because of their skewed distributions (Fig. 1), the average nitrogen and phosphorus contents are not appropriate descriptors of the central tendencies, which are represented better by their median values, which were $1.82 \%$ DW for nitrogen and $0.20 \%$ DW for phosphorus. These values translate to a median C:N:P ratio of $474: 24: 1$, representing $C: P$ and $C: N$ ratios lower than those previously reported for marine macrophytes $(550$ and 30, respectively; Atkinson \& Smith 1984) but considerably greater than those for oceanic seston (106 and 16, respectively; Redfield et al. 1963).

Variability in the carbon content of seagrass leaves (coefficient of variation, $\mathrm{CV}=13 \%$ ) was much less than that in nitrogen $(\mathrm{CV}=40 \%)$ or phosphorus $(\mathrm{CV}=$ $57 \%$ ) contents, probably because most of the carbon content of seagrass leaves represents, as suggested by Atkinson \& Smith (1984), structural components, relatively unaffected by the nutritional status of the plants. The lower variability in seagrass carbon, compared to nitrogen and phosphorus contents also suggests that carbon-limited seagrass growth is, because of high carbon availability in seawater, rare, whereas nitrogen (Short 1987) and phosphorus (Short et al. 1985, Powell et al. 1989, Perez et al. 1990) limitations have been often reported.

Variability in nutrient contents results from differences both within and among species (Figs. 2 to 4 ). However, the importance of differences in nutrient content due to intrinsic differences among species appears small compared to within-species variability, because the range of values exhibited by some species (notably Zostera marina; Figs. 2 to 4 ) is similar to the total range. Further, species with the broadest range of nutrient contents are those for which more measurements were available, suggesting that the range for species with (apparent) smaller variability may be similarly large if additional measurements were available. Since the data set represents the data available, and not a random sample of seagrass nutrient contents, the nutrient contents reported (Figs. 2 to 4 ) reflect the nutritional conditions where the plants were collected, and do not necessarily represent those expected under nutrient-balanced growth.

Because seagrass nitrogen and phosphorus contents were more variable than carbon content, the variability in carbon:nutrient ratios should be dominated by variance in nitrogen and phosphorus, and carbon:nutrient ratios should be proportional to the inverse of the nutrient content in the tissues (Fig. 5). However, the relationship between carbon:nutrient ratio and tissue nutrient content departed significantly from the inverse relationship (i.e. carbon:nutrient $\approx$ nutrient $^{-1}$ ) expected if carbon content were conservative (slope $\log \mathrm{C} / \mathrm{N}-\log \mathrm{N}=$ $-0.84 \pm 0.023 \mathrm{SE}_{i}$ slope $_{\log \mathrm{C} / \mathrm{P}-\log \mathrm{P}}=-0.88 \pm 0.018$ $\mathrm{SE}_{i} \mathrm{H}_{\mathrm{o}}$ : slope $=-1$, t-test, $\mathrm{p}<0.01$ ). The reason for this 


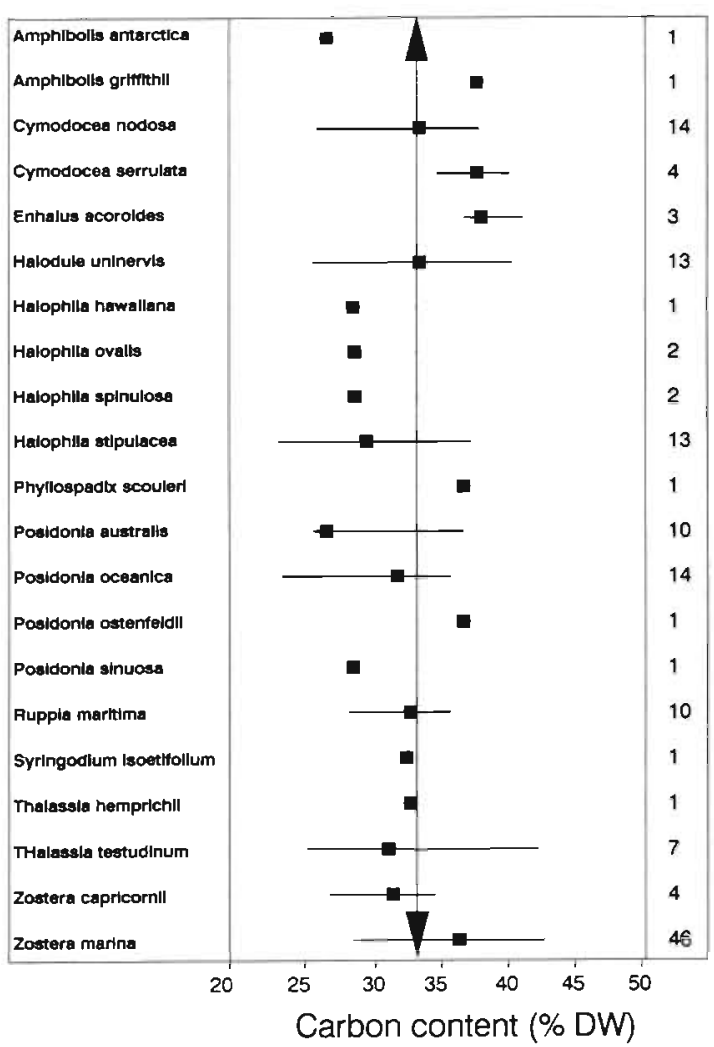

Fig. 2. Carbon contents of the leaves of different seagrass species. Numbers on the right indicate number of measurements; horizontal bars span the entire range of values observed. Vertical arrow: average value

difference is that seagrass carbon content declines at very low nitrogen $(<1.2 \% \mathrm{DW})$ and phosphorus $(<0.13 \%$ DW) contents.

Scaling of seagrass nitrogen or phosphorus content to carbon content provides further insight into seagrass responses to increased nutrient availability. Plants that are strongly nitrogen (or phosphorus) limited should have tissues depleted in nitrogen (or phosphorus) relative to their carbon content, and should, therefore, show high $\mathrm{C}: \mathrm{N}$ (or C:P) ratios (Fig. 5). As nutrient availability increases to meet the plant's demands, their tissues should become progressively enriched in nitrogen and phosphorus relative to the carbon content, implying decreasing $\mathrm{C}: \mathrm{N}$ and $\mathrm{C}: \mathrm{P}$ ratios (Fig. 5). Thus, the rate of change in $\mathrm{C}: \mathrm{N}$ and $\mathrm{C}: \mathrm{P}$ ratios with increasing nitrogen or phosphorus content in plant tissues should shift from high to low as nutrient supply meets the plant's demand, high rates, therefore, indicating nutrient limitation. Indeed, carbon:nitrogen ratios decreased rapidly as leaf nitrogen increased from the minimum observed $(0.56 \%$ DW) to a concentration close to the median value observed (ca $1.8 \% \mathrm{DW}$ ), and decreased slowly as nitrogen concentration increased to about $3.0 \%$ DW (Fig. 5). Similarly, C:P ratios

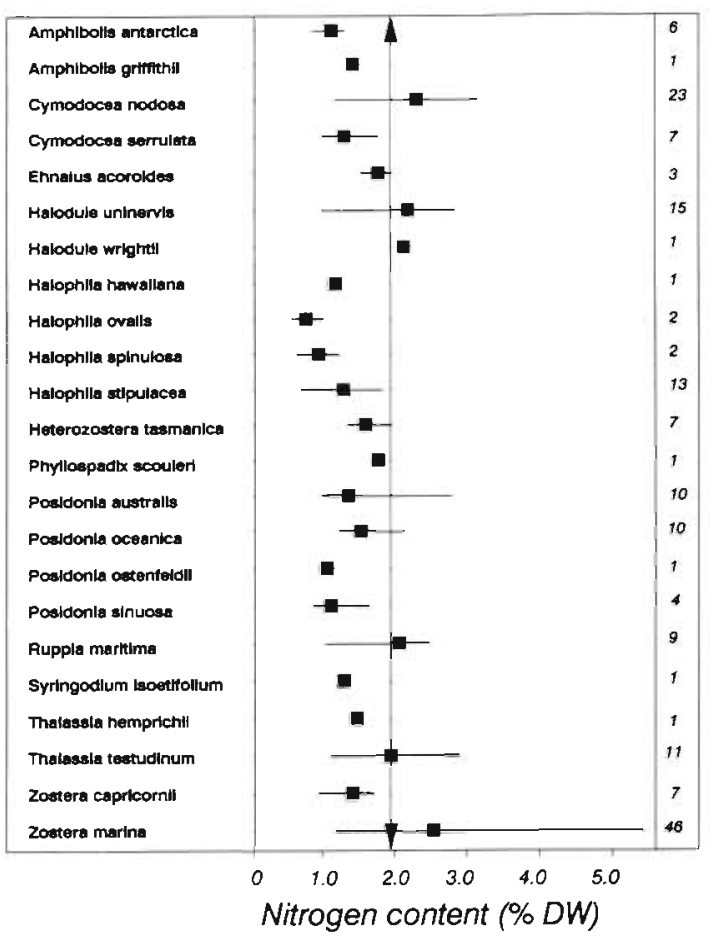

Fig. 3. Nitrogen contents of the leaves of different seagrass species. Numbers on the right indicate number of measurements; horizontal bars span the entire range of values observed. Vertical arrow: median value

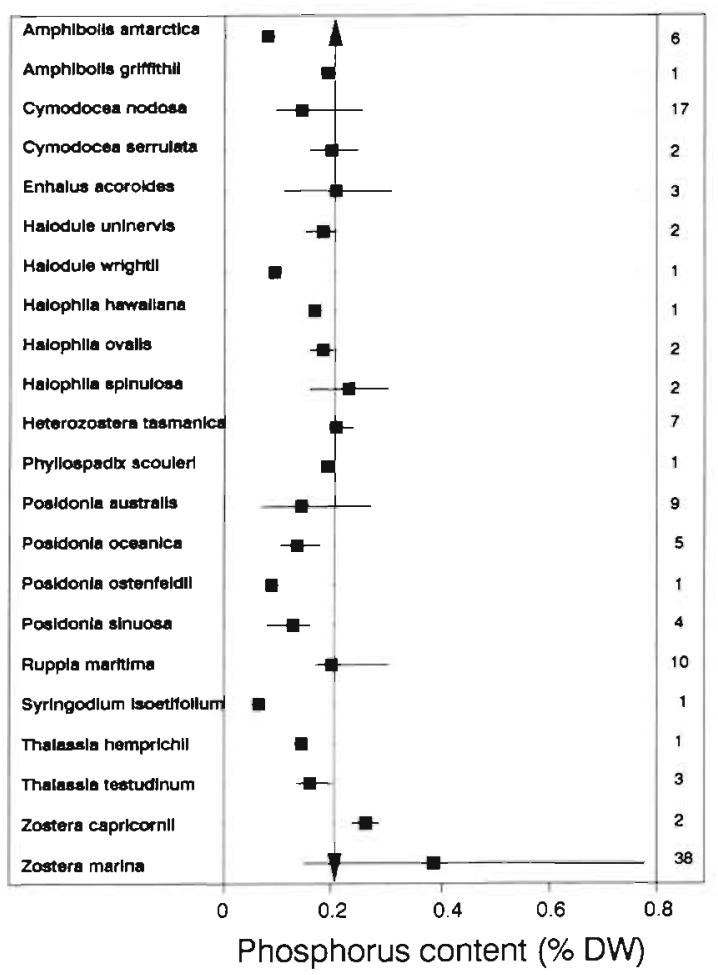

Fig. 4. Phosphorus contents of the leaves of different seagrass species. Numbers on the right indicate number of measurements; horizontal bars span the entire range of values observed. Vertical arrow: median value 

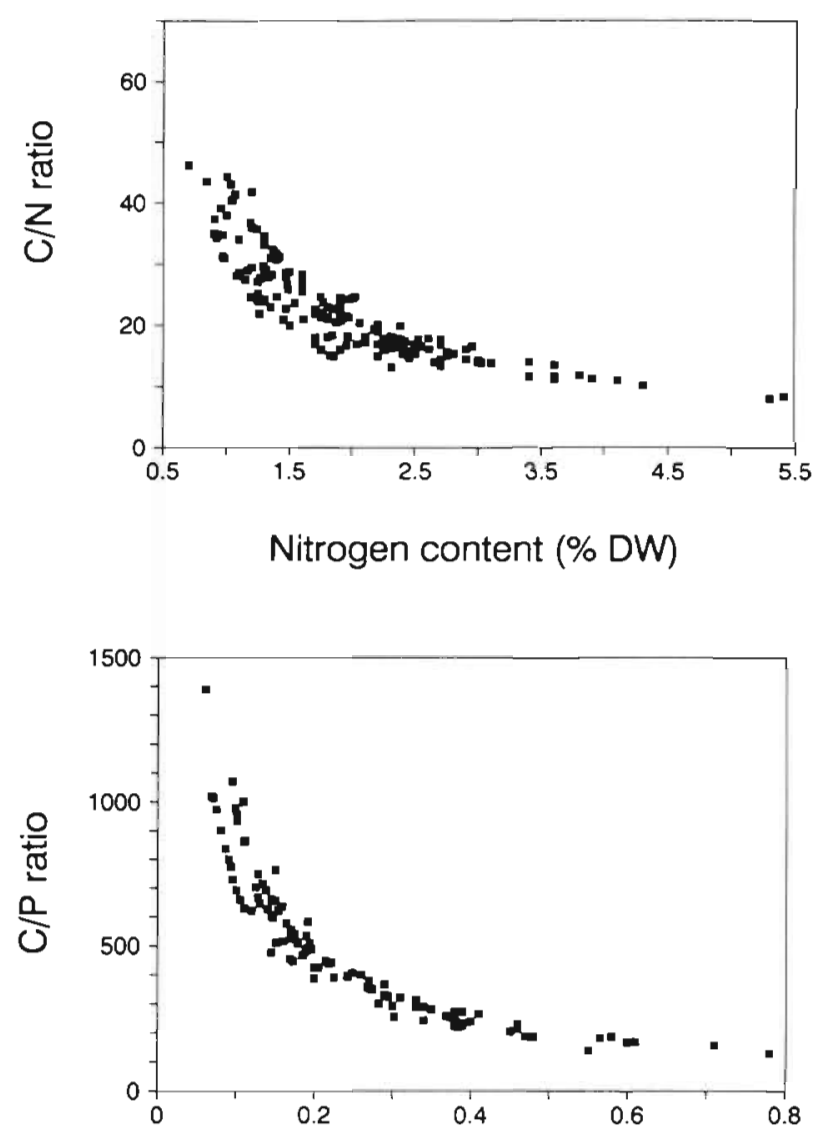

Phosphorus content (\% DW)

Fig. 5. Relationship between carbon:nitrogen (C:N) and carbon:phosphorus (C:P) ratios of seagrass leaves and their nitrogen and phosphorus contents decreased rapidly as phosphorus concentrations increased to values about the median observed $(0.20 \%$ DW), and decreased slowly as phosphorus concentration increased to about $0.40 \%$ DW (Fig. 5). Moreover, the C:N and C:P ratios at which carbon:nutrient ratios appeared stable against further increments in nutrient content were about 12 and 200, respectively (Fig. 5). These values are still higher, but not very much so, than the Redfield ratio for oceanic seston, which is also characteristic of nutrient-balanced growth (Goidman et al. 1979).

The median nutrient contents obtained here may provide a reference to compare data collected in the future. This comparison, however, would only be meaningful if departure from these median values suggested what the nutritional status of the plants might be. Although rigorous evaluation of this possibility requires extensive experimental tests, some indication of its potential merits can be obtained by comparing seagrass response to nutrient enrichment relative to the median nutrient contents reported here. This comparison showed that plants with nutrient contents below the median levels found here $(<1.8 \% \mathrm{~N}$ and $<0.20 \%$ $\mathrm{P}$ as \% DW) were strongly nutrient-limited, as demonstrated by significant increases in tissue nutrient content of enriched plants (Fig. 6). In contrast, the response of plants with nutrient contents similar or greater to the median values was small and statistically not significant (Fig. 6). Identification of critical nutrient contents (cf. Gerloff \& Krombholz 1966) for seagrass growth requires, however, extensive experimental work, for they are likely to vary among species and with changes in growth conditions.

In summary, the results presented here confirm, on
Fig. 6. Seagrass responses, expressed as changes in tissue nutrient content, to nutrient enrichment in relation to median nitrogen and phosphorus contents (vertical arrows). Left-most squares: nutrient contents in unenriched (control) plants; right-most squares: those in enriched ( $\mathrm{P}$ or $\mathrm{N}$ ) plants. Open symbols: non-significant (t-test, $\mathrm{p}>0.05$ responses). Sources of data in Table 1
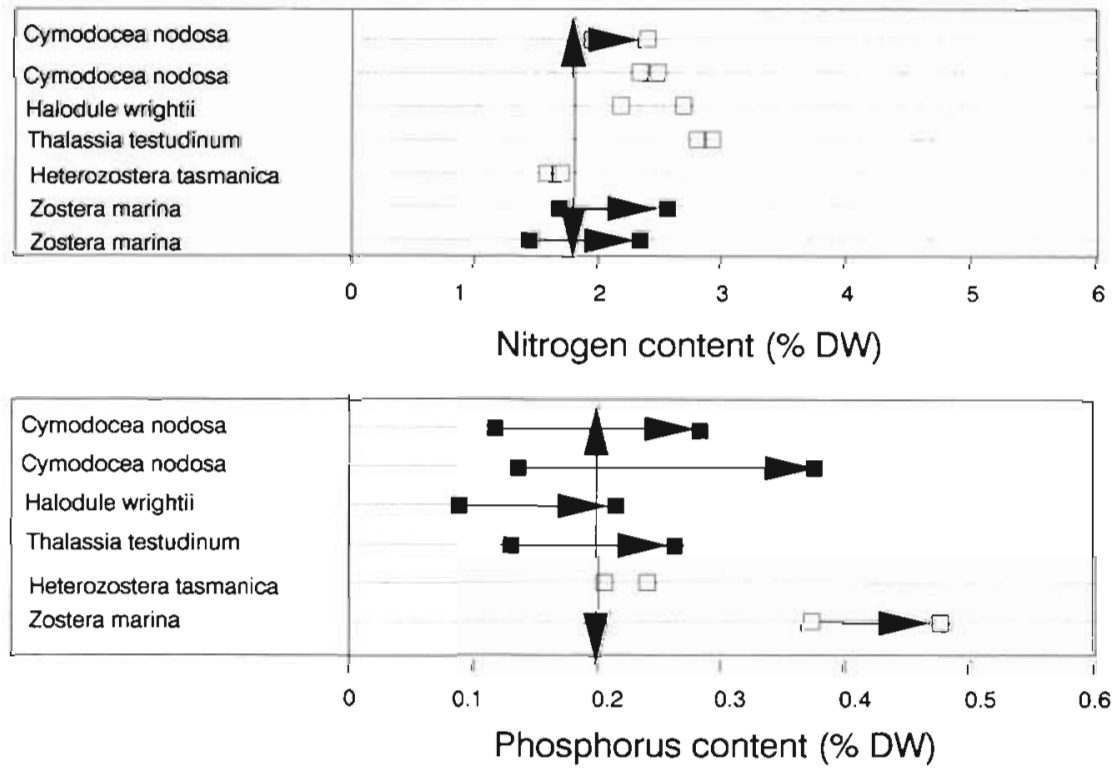
the basis of a much broader compilation of data, the conclusion of Atkinson \& Smith (1984) that C:N:P ratios for seagrasses are, even for very high nutrient availability (as reflected in high nutrient contents), greater than those for oceanic seston, and support their hypothesis that this difference is likely to reflect the greater contribution of structural components to seagrass carbon. Because seagrass carbon shows little variation, changes in carbon:nutrient ( $N$ and $P$ ) ratios are inversely related to changes in nutrient content, and the rate of change in $C: N$ and $C: P$ ratios with increasing nitrogen or phosphorus content in plant tissues should shift from high to small as nutrient supply meets the plant's demands (Fig. 5). The median nitrogen and phosphorus contents reported here $(1.8 \%$ $\mathrm{N}$ and $0.20 \% \mathrm{P}$ as $\% \mathrm{DW}$ ) correctly discriminated between seagrass stands that did or did not respond to nutrient enrichment (Fig. 6). In the absence of information on critical nutrient levels for seagrass growth, these median values may be used to derive predictions on the likelihood of nutrient limitation of seagrass stands upon examination of their nutrient content.

Acknowledgements. I thank K. Sand-Jensen for comments and suggestions on the manuscript.

\section{LITERATURE CITED}

Atkinson, M. J., Smith, S. V. (1984). C:N:P ratios of benthic marine plants. Limnol. Oceanogr. 28: 568-574

Augier, H., Calvert, H., Wollaston, E., Santimonte, M. (1982). A comparison of the $\mathrm{C}, \mathrm{H}, \mathrm{N}$, protein and amino acid composition of Posidonia australis Hook. F. with that of Posidonia oceanica (L.) Delile and several other marine phanerogams. Aquat. Bot. 12: 69-80

Birch, W. P. (1975). Some chemical and calorific properties of tropical marine angiosperms. J. Appl. Ecol. 12: 201-212

Boon, P. I. (1986). Nitrogen pools in seagrass beds of Cymodocea serrulata and Zostera capricorni of Moreton Bay, Australia. Aquat. Bot. 25: 1-19

Bulthuis, D. A., Woelkerling, Wm. J. (1981). Effects of in situ nitrogen and phosphorus enrichment of the sediments on the seagrass Heterozostera tasmanica (Martens ex Aschers.) den Hartog in Western Port, Victoria, Australia. J. Exp. mar. Biol. Ecol. 53: 193-207

Capone, D. G., Penhale, P. A., Oremland, R. S., Taylor, B. F. (1979). Relationship between community productivity and $\mathrm{N}_{2}\left(\mathrm{C}_{2} \mathrm{H}_{2}\right)$ fixation in a Thalassia testudinum community. Limnol. Oceanogr. 24: 117-125

Delgado, O. (1986). Contenido en fósforo de los tejidos de fanerógamas marinas del Mediterráneo occidental y su relación con la dinámica de cada especie. Oecologia Acuática 8: 139-151

Gerloff, G. C., Krombholz, P. H. (1966). Tissue analysis as a measure of nutrient availability for the growth of angiosperm aquatic plants. Limnol. Oceanogr. 11: 529-537

Goldman, J. C., McCarthy, J. J., Peavey, D. G. (1979). Growth rate influence on the chemical composition of phytoplankton in oceanic waters. Nature 279: 210-215

Harlin, M. M., Thorne-Miller, B. (1981). Nutrient enrichment of seagrass beds in a Rhode Island coastal lagoon. Mar. Biol. 65: 221-229

Hocking, P. J., Cambridge, M. L., McComb, A. J. (1981). The nitrogen and phosphorus nutrition of developing plants of two seagrasses, Posidonia australis and Posidonia sinuosa. Aquat. Bot. 11: 245-261

Kenworthy, W. J., Thayer, G. W (1984). Production and decomposition of the roots and rhizomes of seagrass, Zostera marina and Thalassia testudinum in temperate and subtropical marine ecosystems. Bull. Mar. Sci. 35: 364-379

Knauer, G. A., Ayers, A. V. (1977). Changes in carbon, nitrogen, adenosine triphosphate, and chlorophyll $a$ in decomposing Thalassia testudinum blades. Limnol. Oceanogr. 22: 408-414

Patriquin, D. G. (1972). The origin of nitrogen and phosphorus for growth of the marine angiosperm Thalassia testudinum. Mar. Biol. 15: 35-46

Pellikaan, G. C. (1982). Decomposition processes of eelgrass, Zostera manina L. Hydrobiological Bull. 16: 83-92

Pellikaan, G. C., Nienhuis, P. H. (1988). Nutrient uptake and release during growth and decomposition of eelgrass, Zostera marina L., and its effects on the nutrient dynamics of Lake Grevelingen. Aquat. Bot. 30: 189-214

Ретеz, M. (1989). Fanerógamas marinas en sistemas estuáricos: producción, factores limitantes, y algunos aspectos del ciclo de nutrientes. Ph. D. thesis, Universidad de Barcelona, Spain. 244 pp.

Perez, M., Romero, J., Duarte, C. M., Sand-Jensen, K. (1990). Nutrient limitation of Cymodocea nodosa growth: limiting nutrient, growth response, and influence of shoots characteristics. Mar. Biol. (submitted)

Pirc, H., Wollenweber, B. (1988). Seasonal changes in nitrogen, free amino acids, and $\mathrm{C} / \mathrm{N}$ ratio in Mediterranean seagrasses. P.S.Z.N.I. Mar. Ecol. 9: 167-179

Powell, G. V N., Kenworthy, W. J., Fourqueran, J. W. (1989). Experimental evidence for nutrient limitation of seagrass growth in a tropical estuary with restricted circulation. Bull. Mar. Sci. 44: 324-340

Redfield, A. C., Ketchum, B. A., Richards, F. A. (1963) The influence of organisms on the composition of sea-water. pp. 26-77. In: M. N. Hill (ed.) The sea, v. 2. Wiley.

Rublee, P. A., Roman, M. R. (1982). Decomposition of turtlegrass (Thalassia testudinum Konig) in flowing sea-water tanks and litterbags: compositional changes and comparison with natural particulate matter. J. Exp. Mar. Biol. Ecol. 58: $47-58$.

Short, F. T (1983). The response of interstitial ammonium in eelgrass (Zostera marina L.) beds to environmental perturbation. J. Exp. Mar. Biol. Ecol. Ecol. 68: 195-208

Short, F. T. (1987). Effects of sediment nutrients on seagrasses: Literature review and mesocosm experiment. Aquat. Bot. 27: $41-57$

Short, F. T., Davis, M. W., Gibson, R. A., Zimmermann, C. F. (1985). Evidence for phosphate limitation in carbonate sediments of the seagrass Syringodium filiforme. Est. Coastal Shelf Sci. 20: $419-430$

Thayer, G. W., Engel, D. W., LaCroix, M. W. (1977). Seasonal distribution and changes in the nutritive quality of living, dead, and detrital fractions of Zostera marina L. J. Exp. Mar. Biol. Ecol. 30: 109-127.

Umebayashi, O. (1989). Eelgrass productivity on an intertidal flat of Central Japan. Bull. Tokai Reg. Fish. Res. Lab. 127: $17-30$

Umebayashi, O., Sasaki, K. (1985). Distributional pattern of phosphorus, nitrogen, and carbon in a leaf blade of eelgrass, Zostera marina L. Bull. Tokay Reg. Fish. Res. Lab. 118: 21-32 
Wahbeh, M. 1. (1988). Seasonal distribution and variation in the nutritional quality of different fractions of two seagrass species from Aqaba (Red Sea). Jordan. Aquat. Bot. 32: 383-392

Walker, D. I., McComb, A. J. (1988). Seasonal variation in the production, biomass, and nutrient status of Amphibolis antarctica (Labill.) Sonder ex Aschers, and Posidonia australis Hook. F. in Shark Bay, Western Australia. Aquat. Bot. 31: 259-275

This article was presented by Dr G. W. Thayer, Beaufort, North Carolina, USA
Zieman, J. C., Iverson, Ogden, J. C. (1984). Herbivory effects on Thalassia testudinum leaf growth and nitrogen content. Mar. Ecol. Prog. Ser. 15: 151-158

Zimmermann, R. C., Smith, R. D., Alberte, R. S. (1987). Is growth of eelgrass nitrogen limited? A numerical simulation of the effects of light and nitrogen on the growth dynamics of Zostera marina. Mar Ecol. Prog. Ser. 41: $167-176$

Revised version accepted: July 27, 1990 